\title{
Predictors of Sexual Dysfunction in HIV-Infected Women
}

\author{
Zeinab Moshfeghy ${ }^{1}$, Fatemeh Dadgar ${ }^{2}$, Roksana Janghorban ${ }^{3}$, Tahereh Poordast ${ }^{4}$ \\ ${ }^{1}$ Student Research Committee, Department of Midwifery and Reproductive Health, \\ School of Nursing and Midwifery, Shahid Beheshti University of Medical Sciences, Tehran, Iran \\ ${ }^{2} M S c$ in Midwifery, Student Research Committee, Department of Midwifery, \\ School of Nursing and Midwifery, Shiraz University of Medical Sciences, Shiraz, Iran \\ ${ }^{3}$ Department of Midwifery, School of Nursing and Midwifery, \\ Community-Based Psychiatric Care Research Center, Shiraz University of Medical Sciences, Shiraz, Iran \\ ${ }^{4}$ Department of Obstetrics and Gynecology, School of Medicine, Infertility Research Center, \\ Shiraz University of Medical Sciences, Shiraz, Iran
}

\section{SUMMARY}

Sexual dysfunction is more common among the people with human immunodeficiency virus (HIV) infection than in those without it. The sexual dysfunction in HIV-infected people is associated with adverse outcomes such as reduced quality of life, unprotected sexual activities, and reduced adherence to highly active antiretroviral therapy. Therefore, the present study was designed to investigate a potential predictor role of some variables such as socioeconomic status, hormonal and HIV disease profile, type of treatment, depression, anxiety, stress, domestic violence, and status of partner infection for sexual function in people with HIV infection.

This descriptive cross-sectional study was conducted on $40 \mathrm{HIV}$-infected women with medical records in behavioral disease counseling centers of Shiraz University of Medical Sciences. The required data were collected using the Female Sexual Function Index (FSFI), Depression, Anxiety, Stress Scale (DASS-21), and Domestic Violence Questionnaire. To examine the CD4 cell levels and hormonal profiles, $5 \mathrm{cc}$ blood was taken from the patients simultaneously on days $3-5$ of their menstrual cycles. The data were analyzed using the SPSS18 software.

The mean age of the participants was $38.2 \pm 5.2$ years, and the frequency of sexual dysfunction was $100 \%$. There was a statistically significant difference in the levels of the elevated variables such as estradiol, stress, anxiety, and depression. The multivariate analysis showed that only the increased estradiol level $(P=0.005, B=0.06)$ was a predictor factor of sexual dysfunction.

All the HIV-infected women had sexual dysfunction. The results of this study showed that in those women the increased levels of estradiol could be a predictor of sexual dysfunction.

Key words: sexual dysfunction, human immunodeficiency virus, acquired immunodeficiency syndrome, depression, stress 


\section{INTRODUCTION}

Since the outbreak of the human immunodeficiency virus (HIV) infection, more than seventy million people have been infected and about thirtyfive million have died of it. Overall, 36.9 million people were infected by the end of 2017 (1). According to the World Health Organization (WHO) in 2018, the prevalence of HIV infection in Iran was 36,571 people, and the number of new HIV cases was 4,661 in 2017 (2). Women's physiology makes them more susceptible to HIV infection because a wider surface of vaginal mucous membrane is exposed to male secretions and the exposure is more likely to increase in case of genital trauma (3). HIV infection and sexual dysfunction are currently two important and significant problems in women. On the other hand, studies have shown that sexual dysfunction is very common among HIV-infected women, and due to the taboo of sexual dysfunction in many countries and the negative perception and social stigma existing in societies for HIV infection, the infected individuals' sexual issues have received less attention $(4-7)$. There are several reasons for the higher prevalence of sexual dysfunction in HIV-infected women than in those without such an infection. In addition to the risk factors associated with sexual dysfunction in general population, such as psychological problems and drug abuse $(8,5)$, HIV-infected women's fear of transmission risk as well as the stigma associated with the infection and the alteration in body image could be other reasons for the higher prevalence of sexual dysfunction in these women $(9,10)$. Sexual dysfunction in HIV-infected people is associated with reduced quality of life, unprotected sexual activity, and decreased adherence to highly active antiretroviral therapy (4, $11,12)$. Considering the undesirable consequences of sexual dysfunction in women with HIV, it is very important to investigate the predictors of this disorder. Hence, the aim of this study was to determine the predictors of sexual function in HIV-infected women.

\section{PARTICIPANTS AND METHODS}

This descriptive cross-sectional study was conducted from December 2018 to March 2019 in behavioral disease counseling centers of Shiraz University of Medical Sciences, Iran, after receiving the Ethics Code IR.SUMS.REC.1397.386 from the National Ethics Committee on Biomedical Research. The inclusion criteria were Iranian nationality, being woman, HIV infection confirmation by undergoing a rapid detection test and then the ELISA with two kits from two different generations, and having medical records in the behavioral disease counseling centers. The subjects could be excluded at any stage if they did not consent to participate, without affecting their treatment process. Samples were selected according to convenience sampling from women who had complete medical records and inclusion criteria. After stating the aims of the study, examining the inclusion and exclusion criteria, and obtaining the subjects' written informed consent, their demographic information, fertility profile, history of disease, surgery, drug use, smoking, substance abuse, and alcohol abuse, number of sexual partners, contraception methods, condom use, sexual partner's status in terms of HIV infection, and adherence to treatment within the last six months prior to the study were collected by a researchermade questionnaire. The Female Sexual Function Index (FSFI), the reliability and validity of which had been determined by Rosen et al. in 2000, was then completed by the subjects (13). That 19-item questionnaire examined the women's sexual function in six domains including sexual desire, sexual arousal, lubrication, orgasm, satisfaction and pain over the past four weeks on a 6-point Likert scale ranging from 0 to 5 . Each domain was scored by summing up the scores of the questions on the domain and multiplying it by the factor number. Since the number of questions on the domains differed, first the weights of the domains were equalized by summing up the scores of the questions on each domain and multiplying by the factor number. To equalize the weights of the domains, the maximum scores of each domain and the whole scale would be 6 and 36, respectively $(13,14)$. The cut-off points for the whole scales and the subscales were as follows: whole scale 28; desire 3.3; psychological stimulus 3.4; lubrication 3.4; orgasm 3.4; satisfaction 3.8; and sexual pain 3.8. In other words, the scores higher than the cut-off point indicated normal sexual function (14). The Depression, Anxiety, Stress Scale (DASS-21), the validity and reliability of which had been determined by Anthony et al. in 1998, was also completed by the participants (15). This 21-item questionnaire which was scored based on a 4-point Likert-scale ranged from 0 to 3 assessed the depression, anxiety, and stress status of the individuals over the past four weeks. In the depression domain, the scores 0 to 9 showed a normal status, 10 to 13 showed mild, 14 to 
20 indicated moderate, 21 to 27 indicated severe, and over 27 showed very severe depression. Regarding anxiety, the scores 0 to 7 showed normal, 8 to 9 showed mild, 10 to 14 indicated moderate, 15 to 19 showed severe, and over 19 indicated very severe anxiety. Besides, the scores 0 to 14 showed normal, 15 to 18 indicated mild, 19 to 25 showed moderate, 26 to 33 indicated severe, and the scores over 33 showed very severe stress (16).

The information on disease status including the time elapsed from diagnosis, type of current treatment, and type of treatment regimen were extracted from the patients' medical records. In this study, each HIV-infected woman was taken 5cc blood by the experienced laboratory staff on days 3-5 of her menstrual cycles. The blood samples were sent to a certain laboratory, and the levels of testosterone, estradiol, progesterone, dehydroepiandrosterone sulfate, sex hormone binding globulin, cortisol, thyroid stimulating hormone, and thyroxine were measured through ELISA, and the CD4 cell levels were also measured using the Flow cytometry method by a laboratory staff.

The data were analyzed using the SPSS18 software. The Mann-Whitney and Kruskal-Wallis tests were also used to compare the sexual function scores in different groups of variables. To determine the relationship between quantitative variables and the mean sexual function score, the Spearman correlation coefficient was used as well. Then, the variables that had a significant relationship with sexual function were entered in the linear regression test. The significance level was considered lower than 0.05 .

\section{RESULTS}

The mean age of the 40 participants in this study was $38.2 \pm 5.2$ years. Regarding the marital status, $95 \%$ of the subjects were married, $2.5 \%$ were divorced, and $2.5 \%$ were widowed. Only $12.5 \%$ of the women participating in this study had academic education, and $87.5 \%$ had an income below 5,000,000 IRR. Besides, the mean body mass index of the women was $25.3 \pm 6 \mathrm{~kg} / \mathrm{m}^{2}$. In the women with HIV infection, the mean diagnosis and treatment time was $6 \pm 3.5$ and $4.8 \pm 2.8$ years, respectively. The information on women's disease status is shown in Table 1 . The prev-

Table 1. Information on disease status of HIV-infected women

\begin{tabular}{|c|c|}
\hline Variables & Number $(\%)$ \\
\hline Disease stage (WHO classification) & \multirow[b]{2}{*}{$33(82.5)$} \\
\hline 1 & \\
\hline 2 & $3(7.5)$ \\
\hline 3 & $1(2.5)$ \\
\hline 4 & $3(7.5)$ \\
\hline CD4 cell count $\left(\right.$ cells $\left./ \mathbf{m m}^{3}\right)$ & \multirow[b]{2}{*}{$2(5)$} \\
\hline$\leq 199$ & \\
\hline $200-499$ & $20(50)$ \\
\hline$\leq 500$ & $18(19.9)$ \\
\hline Getting HAART * & \multirow[b]{2}{*}{$39(97.5)$} \\
\hline Yes & \\
\hline No & $1(2.5)$ \\
\hline Type of antiretroviral treatment & \multirow[b]{2}{*}{$38(95)$} \\
\hline${ }^{* *}$ NRTI $+{ }^{* * *}$ NNRTI use & \\
\hline NRTI ${ }^{* * * *}$ PI use & $1(2.5)$ \\
\hline \multicolumn{2}{|l|}{ Adherence to treatment } \\
\hline$<90 \%$ & -- \\
\hline $90-95 \%$ & -- \\
\hline$>95 \%$ & $39(100)$ \\
\hline \multicolumn{2}{|c|}{$\begin{array}{l}\text { *HAART= Highly active antiretroviral therapy } \\
\text { *NATI = Nucleoside reverse transcriptase inhibitor } \\
{ }^{* * * *} \text { NNRTI= Non-nucleoside reverse transcriptase inhibitor } \\
{ }^{* * * *} \text { PI= Protease inhibitor }\end{array}$} \\
\hline
\end{tabular}


Table 2. Sexual dysfunction status in HIV-infected women using Female Sexual Function Index

\begin{tabular}{l|c|c|c|c|c|c|c}
\hline \hline & $\begin{array}{c}\text { Overall } \\
\text { function }\end{array}$ & Desire & Arousal & Lubrication & Orgasm & $\begin{array}{c}\text { Sexual } \\
\text { satisfaction }\end{array}$ & Pain \\
\hline Cut-off points & $\leq 28$ & $\leq 3 / 3$ & $\leq 3 / 4$ & $\leq 3 / 4$ & $\leq 3 / 4$ & $\leq 3 / 8$ & $\leq 3 / 8$ \\
\hline Frequency & 40 & 40 & 17 & 23 & 14 & 12 & 38 \\
\hline Percentage & 100 & 100 & $42 / 5$ & $57 / 5$ & 35 & 30 & 95 \\
\hline \hline
\end{tabular}

Table 3. Risk factors associated with female sexual dysfunction in females living with HIV

\begin{tabular}{|c|c|c|c|}
\hline Factor & $\begin{array}{l}\text { Sexual dysfunction, } \\
N(\%) \mathrm{N}=40\end{array}$ & $\begin{array}{l}\text { FSFI Score } \\
\text { Mean } \pm \text { SD }\end{array}$ & $\begin{array}{l}\text { P value } \\
\text { (univariate association } \\
\text { with FSFI score) }\end{array}$ \\
\hline Marital status & \multirow{6}{*}{$\begin{array}{l}-- \\
7(17.5) \\
31(77.5) \\
1(2.5) \\
1(2.5)\end{array}$} & \multirow{6}{*}{$\begin{array}{l}-- \\
31.1 \pm 8.1 \\
29.1 \pm 9.3 \\
26.7 \pm 5.4 \\
29.2 \pm 9.3\end{array}$} & \multirow{6}{*}{0.21} \\
\hline Single & & & \\
\hline Temporary & & & \\
\hline Permanent & & & \\
\hline Divorced & & & \\
\hline Widow & & & \\
\hline $\begin{array}{l}\text { Status of partner infection } \\
\text { with HIV }\end{array}$ & \multirow{4}{*}{$\begin{array}{l}23(57.5) \\
16(40) \\
1(2.5)\end{array}$} & \multirow{4}{*}{$\begin{array}{l}18.8 \pm 5.2 \\
21.7 \pm 5.2 \\
25.2\end{array}$} & \multirow{4}{*}{0.052} \\
\hline Positive & & & \\
\hline Negative & & & \\
\hline Undetermined & & & \\
\hline Educational level & \multirow{6}{*}{$\begin{array}{l}1(2.5) \\
13(32.5) \\
11(27.5) \\
10(25) \\
5(12.5) \\
\end{array}$} & \multirow{6}{*}{$\begin{array}{l}18.4 \pm 3.5 \\
21.4 \pm 3.8 \\
21.9 \pm 3.3 \\
17.9 \pm 7.1 \\
17.7 \pm 7.6 \\
\end{array}$} & \multirow{6}{*}{0.3} \\
\hline Illiterate & & & \\
\hline Primary school & & & \\
\hline Secondary school & & & \\
\hline High school & & & \\
\hline Academic education & & & \\
\hline Occupation & \multirow{3}{*}{$\begin{array}{l}5(12.5) \\
35(87.5)\end{array}$} & \multirow{3}{*}{$\begin{array}{l}15.6 \pm 0.21 \\
20.1 \pm 5.4\end{array}$} & \multirow{3}{*}{0.24} \\
\hline Employed & & & \\
\hline Housewife & & & \\
\hline Monthly income & \multirow{3}{*}{$\begin{array}{l}35(87.5) \\
5(12.5)\end{array}$} & \multirow{3}{*}{$\begin{array}{l}20.2 \pm 5.5 \\
19.5 \pm 4.2\end{array}$} & \multirow[b]{3}{*}{0.12} \\
\hline$<5000000$ IRR & & & \\
\hline $\begin{array}{l}\text { 5000000-15000000 IRR } \\
>15000000 \text { IRR }\end{array}$ & & & \\
\hline Sexual intercourse route & \multirow{4}{*}{$\begin{array}{l}32(80) \\
7(17.5) \\
1(2.5)\end{array}$} & \multirow{4}{*}{$\begin{array}{l}20 \pm 5.3 \\
19 \pm 6.1 \\
23\end{array}$} & \multirow{4}{*}{0.56} \\
\hline Vaginal & & & \\
\hline Vaginal-rectal & & & \\
\hline Oral-vaginal & & & \\
\hline Prevention method & \multirow{3}{*}{$\begin{array}{l}36(90) \\
4(10)\end{array}$} & \multirow{3}{*}{$\begin{array}{l}20.3 \pm 5.3 \\
18.6 \pm 5.7\end{array}$} & \multirow{3}{*}{0.55} \\
\hline Condom & & & \\
\hline Tubectomy & & & \\
\hline Positive rape history & $1(2.5)$ & 23.6 & 0.51 \\
\hline Medication & \multirow{4}{*}{$\begin{array}{l}2(5) \\
2(5) \\
4(10)\end{array}$} & \multirow{4}{*}{$\begin{array}{l}22 \pm 1.4 \\
17.4 \pm 4.5 \\
19.4 \pm 4.5\end{array}$} & \multirow{4}{*}{$\begin{array}{l}0.44 \\
0.54 \\
0.55\end{array}$} \\
\hline Blood pressure & & & \\
\hline High cholesterol & & & \\
\hline Antidepressant & & & \\
\hline Disease & \multirow{3}{*}{$\begin{array}{l}4(10) \\
4(10)\end{array}$} & \multirow{3}{*}{$\begin{array}{l}21.6 \pm 1.5 \\
19.4 \pm 4.5 \\
\end{array}$} & \multirow{3}{*}{$\begin{array}{l}0.45 \\
0.23 \\
\end{array}$} \\
\hline Cardiovascular disease & & & \\
\hline Psychiatry disorder & & & \\
\hline
\end{tabular}




\begin{tabular}{l|l|l|l}
\hline \hline Smoker & $2(5)$ & $16.2 \pm 3.1$ & 0.75 \\
\cline { 1 - 4 } WHO clinical stage & & & \\
2 & $33(82.5)$ & $20.1 \pm 5.2$ & \\
3 & $3(7.5)$ & $20.4 \pm 7.6$ & 0.78 \\
4 & $1(2.5)$ & 20.1 & \\
\hline HAART & $3(7.5)$ & $20 \pm 4.2$ & \\
\hline NRTI+NNRTI based & $39(97.5)$ & $20.1 \pm 5.3$ & 0.73 \\
NRTI+PI- based & $38(95)$ & $19.9 \pm 5.4$ & 0.56 \\
\hline Adherence to HAART & $1(2.5)$ & 21 & \\
\hline$<90 \%$ & -- & & \\
$90-95 \%$ & -- & -- & \\
$>95 \%$ & $39(100)$ & $20 \pm 5.4$ & \\
\hline CD4cell count(cells/mm $\left.{ }^{3}\right)$ & $2(5)$ & $18.8 \pm 10.1$ & \\
\hline$\leq 199$ & $20(50)$ & $20.3 \pm 5.6$ & 0.9 \\
$200-499$ & $18(45)$ & $19.9 \pm 4.8$ & \\
$\geq 500$ & &
\end{tabular}

Table 4. Spearman's correlation of female sexual dysfunction with age, BMI, time on HAART, duration of HIV infection, age at menarche, parity, sexual hormones, stress, anxiety and depression

\begin{tabular}{l|c|c}
\hline \multicolumn{3}{c}{ Total FSFI } \\
\hline Factor & $\mathrm{R}$ & $\mathrm{P}$ \\
\hline Age $($ years) & -0.13 & 0.39 \\
\hline${ }^{*}$ BMI $\left(\mathrm{kg} / \mathrm{m}^{2}\right)$ & -0.17 & 0.28 \\
\hline Time on HAART (years) & -0.21 & 0.2 \\
\hline Duration of HIV infection (years) & -0.12 & 0.45 \\
\hline Age at menarche (years) & -0.05 & 0.75 \\
\hline Parity & -0.037 & 0.82 \\
\hline${ }^{* *}$ SHBG (nmol/L) & 0.027 & 0.87 \\
\hline Cortisol $(\mu \mathrm{g} / \mathrm{dL})$ & -0.16 & 0.32 \\
\hline${ }^{* * *} \mathrm{TSH}(\mathrm{IU} / \mathrm{mL})$ & -0.09 & 0.58 \\
\hline${ }^{* * * *} \mathrm{~T} 4(\mu \mathrm{g} / \mathrm{dL})$ & 0.052 & 0.75 \\
\hline${ }^{* * * * *} \mathrm{FSH}(\mathrm{mIU} / \mathrm{mL})$ & -0.078 & 0.63 \\
\hline${ }^{* * * * * *} \mathrm{LH}(\mathrm{mIU} / \mathrm{mL})$ & -0.21 & 0.21 \\
\hline Testestrone $(\mathrm{ng} / \mathrm{dL})$ & 0.09 & 0.54 \\
\hline${ }^{* * * * * * *} \mathrm{DHEAS}(\mathrm{Microgr} / \mathrm{dl})$ & -0.17 & 0.28 \\
\hline Estradiol $(\mathrm{pg} / \mathrm{mL})$ & -0.43 & 0.005 \\
\hline Progesteron $(\mathrm{ng} / \mathrm{mL})$ & -0.12 & 0.47 \\
\hline Stress & -0.13 & $<0.001$ \\
\hline Anxiety & -0.05 & $<0.001$ \\
\hline Depression & -0.13 & $<0.001$ \\
\hline \hline
\end{tabular}

Univariate analysis ( $r$, Spearman correlation; P statistical significance)

*BMI = body mass index;

**SHBG $=$ Sex hormone binding globulin;

***TSH = Thyroid stimulating hormone;

****T4 = Thyroxine hormone;

***** $\mathrm{FSH}=$ Follicle-stimulating hormone;

****** $\mathrm{LH}=$ Luteinizing hormone;

*******DHEAS= Dehydroepiandrosterone sulfate 
alence of concurrent diseases that could potentially cause sexual dysfunction was low. Four women (10\%) had cardiovascular disease, four $(10 \%)$ had neuropsychiatric illness, two (5\%) had diabetes, two (5\%) were treated with blood pressure control drugs, and two women $(5 \%)$ were under treatment with diabetes control drugs.

In the present study, the mean score of FSFI was $18.3 \pm 5.1$, and $100 \%$ of the HIV-infected women in this study reported sexual dysfunction in overall function (Table 2). Among the variables measured, there was a statistically significant difference in elevated levels of estradiol, stress, anxiety, and depression (Tables 3 and 4). The variables related to sexual function were included in the linear regression in order for their predictive role to be determined. The multivariate analysis showed that only the elevated estradiol level $(P=0.005, B=0.06)$ was a predictor of sexual dysfunction.

\section{DISCUSSION}

In this study, we found 40 HIV-positive women who had sexual dysfunction and the only predictor of this dysfunction was an elevated estradiol level. The analysis of the data on the prevalence of sexual dysfunction in HIV-infected women showed that all the women in this study $(100 \%)$ were suffering from overall sexual dysfunction which was significantly higher than the rate reported for the 43 women with human immunodeficiency virus infection in the study carried out by Pinzone et al. (17) in Italy, who stated that $34.4 \%$ of the HIV-infected women had sexual dysfunction. In the present study, more than two-thirds of the women $(70 \%)$ were suffering from anxiety, of whom $35 \%$ had severe to very severe anxiety. However, in the study by Pinzone, $53.1 \%$ of the women reported the symptoms of anxiety. Hence, it seems that the impact of high levels of anxiety on the individuals' sexual function might partially explain the difference between the results of the two studies. Also, in a study by Oyedokun et al. (18) in Nigeria, the frequency of sexual dysfunction in HIV-infected women was reported to be $61 \%$, and it seems that the difference with the frequency reported in the present study could be the difference between the sample sizes in the two studies. The number of women participating in Oyedokun's study was 370. In the present study, the univariate analysis showed a statistically significant difference in the elevated levels of estradiol, stress, anxiety and depression, but the multivariate analysis showed that only elevated levels of estradiol were predictors of overall sexual function. The results of this study indicated that increased levels of estradiol could be a predictor of sexual dysfunction. The results of the study by Lema (11) in 2004 on the men with human immunodeficiency virus infection showed that taking antiretroviral drugs increased estradiol levels. The results of a review by Wuttke et al. (19), aimed at defining, classifying and identifying the mechanism of action of endocrine-disrupting chemicals, showed that substances such as soy isoflavones, Bisphenol A, dibutyl phthalate, and cinnamate, used as drugs in industries, had an estrogen agonist mechanism of action and inhibited adrenal steroid secretion, produced thyroxine (hypothyroidism), and increased estrogen levels in the blood, causing sexual dysfunction and affecting the reproduction system and mammary glands. According to the study by Lema and given that $97.5 \%$ of the women in the present study were under treatment with antiretroviral drugs, it seems that elevated levels of estradiol were a predictor of sexual dysfunction for the high percentage of this disorder in the study.

According to our knowledge, this study is the first study in Iran conducted to investigate the predictors of sexual function in HIV-infected women. In this study, the status of the predictors of female sex hormones such as blood cortisol, progesterone, sex hormone binding globulin, dihydroepiandrosterone sulfate, testosterone, follicle-stimulating hormone, luteinizing hormone, thyroid stimulating hormone, thyroxine and estradiol was also evaluated.

The limitations of this study were the small sample size and the lack of a questionnaire specific for people with HIV infection to assess their stress, depression and anxiety.

\section{CONCLUSION}

The results of this study showed that all the women with HIV infection had sexual dysfunction, and elevated estradiol levels could predict their sexual dysfunction. It is suggested that health care providers who work in behavioral disease counseling centers should assess sexual function of HIVpositive women. The early assessment and treatment could improve their sexual health and prevent the adverse consequences of not identifying and treating these dysfunctions. 


\section{Conflict of interest}

The authors declare that they have no conflict of interest.

\section{References}

1. World Health Organization. Prevalence of HIV; 2018. Available from: https://www.who.int/news-room/factsheets/detail/hiv-aids

2. Prevalence of HIV in Iran; 2018. Available from: https://www.unaids.org/en/dataanalysis/knowyo urresponse/countryprogressreports/2018countries

3. Higgins JA, Hoffman S, Dworkin SL. Rethinking gender, heterosexual men, and women's vulnerability to HIV/AIDS. Am J Public Health 2010;100:435-45.

https://doi.org/10.2105/AJPH.2009.159723

4. Wilson TE, Jean-Louis G, Schwartz R, et al. HIV infection and women's sexual functioning. J Acquir Immune Defic Syndr 2010;54:360-67. https://doi.org/10.1097/QAI.0b013e3181d01b14

5. Bouhlel S, Derbel C, Nakhli J, et al. Sexual dysfunction in Tunisian patients living with HIV. Sexologies 2017;26:e11-e16.

https://doi.org/10.1016/j.sexol.2016.09.003

6. Charles B, Jeyaseelan L, Pandian AK, et al. Association between stigma, depression and quality of life of people living with HIV/AIDS (PLHA) in South India-a community based cross sectional study. BMC Public Health 2012;12:463. https://doi.org/10.1186/1471-2458-12-463

7. Nusbaum M, Rosenfeld JA. Sexual health across the lifecycle: a practical guide for clinicians. $1^{\text {st }} \mathrm{ed}$. Cambridge: Cambridge University Press; 2004.
https://doi.org/10.1017/CBO9780511584480

8. Bhatia M, Munjal S. Prevalence of depression in people living with HIV/AIDS undergoing ART and factors associated with it. J Clinical Diagn Res. 2014;8:WC01-4

https://doi.org/10.7860/JCDR/2014/7725.4927

9. Kaida A, Carter A, de Pokomandy A, et al. Sexual inactivity and sexual satisfaction among women living with HIV in Canada in the context of growing social, legal and public health surveillance. J Int AIDS Soc 2015;18:20284.

https://doi.org/10.7448/IAS.18.6.20284

10. Luzi K, Guaraldi G, Murri R, et al. Body image is a major determinant of sexual dysfunction in stable HIV-infected women. Antivir Ther 2009;14:85-92.

11. Lema VM. Sexual dysfunction among HIV patients: three case reports and review of literature. Afr J Reprod Health 2013;17:161-70.

12. Bouhnik A-D, Préau M, Schiltz M-A, et al. VESPA study group. Sexual difficulties in people living with HIV in France-results from a large representative sample of outpatients attending French hospitals (ANRS-EN12-VESPA). AIDS Behav 2008;12:670-76. https://doi.org/10.1007/s10461-007-9355-z

13. Rosen R, Brown C, Heiman J, et al. The Female Sexual Function Index (FSFI): a multidimensional self-report instrument for the assessment of female 
sexual function. J Sex Marital Ther 2000;26:191-208. https://doi.org/10.1080/009262300278597

14. Mohammadi K, Heydari M, Faghihzadeh S. The female sexual function index (FSFI): validation of the Iranian version. Payesh 2008;7:269-78.

15. Antony MM, Bieling PJ, Cox BJ, et al. Psychometric properties of the 42-item and 21-item versions of the Depression Anxiety Stress Scales in clinical groups and a community sample. Psychol Assess 1998;10:176-81.

https://doi.org/10.1037/1040-3590.10.2.176

16. Lovibond $\mathrm{PF}$, Lovibond $\mathrm{SH}$. The structure of negative emotional states: Comparison of the Depression Anxiety Stress Scales (DASS) with the Beck Depression and Anxiety Inventories. Behav Res Ther 1995;33:335-43
https://doi.org/10.1016/0005-7967(94)00075-U

17. Pinzone MR, Guss M, Bellissimo F, et al. selfreported sexual dysfunction in HIV-positive subjects:a cross-sectional study. Infect Dis Trop Med 2015;1:1-5.

18. Oyedokun A, Odeigah L, Alabi K, Adegunloye O, Akujobi H. Sexual Dysfunction in HIV-Positive Women Attending a Tertiary Health Facility in North Central Nigeria. J AIDS Clin Res 2014;5:398. https://doi.org/10.4172/2155-6113.1000398

19. Wuttke W, Jarry H, Seidlova-Wuttke D. Definition, classification and mechanism of action of endocrine disrupting chemicals. Hormones 2010;9:9-15. https://doi.org/10.1007/BF03401276 


\title{
Prediktori seksualne disfunkcije kod žena zaraženih HIV-om
}

\author{
Zeinab Moshfeghy ${ }^{1}$, Fatemeh Dadgar ${ }^{2}$, Roksana Janghorban ${ }^{3}$, Tahereh Poordast ${ }^{4}$ \\ ${ }^{1}$ Studentski istraživački komitet, Departman za akušerstvo i reproduktivno zdravlje, \\ Fakultet za sestrinstvo i akušerstvo, Univerzitet medicinskih nauka Šahid Behešti, Teheran, Iran \\ ${ }^{2}$ Magistar akušerstva, Studentski istraživački komitet, Departman za akušerstvo, \\ Fakultet za sestrinstvo i akušerstvo, Univerzitet medicinskih nauka u Širazu, Širaz, Iran \\ ${ }^{3}$ Departman za akušerstvo, Fakultet za sestrinstvo i akušerstvo, Društveni psihijatrijski centar za istraživanja, \\ Univerzitet medicinskih nauka u Širazu, Širaz, Iran \\ 4Departman za akušerstvo i ginekologiju, Medicinski fakultet, Centar za ispitivanje neplodnosti, \\ Univerzitet medicinskih nauka u Širazu, Širaz, Iran
}

\section{S AŽETAK}

Seksualna disfunkcija češće se javlja kod ljudi inficiranih humanim imunodeficijentnim virusom (HIV). Seksualna disfunkcija kod ljudi inficiranih ovim virusom dovodi se u vezu sa nekim nepovoljnim ishodima, poput smanjenog kvaliteta života, nezaštićenog seksualnog odnosa i neredovnog pridržavanja visoko aktivnoj antiretroviralnoj terapiji. Cilj ove studije bio je da ispita potencijalne prediktivne uloge nekih varijabli, poput socioekonomskog statusa, hormoskog statusa, profila bolesti izazvane HIV-om, vrste lečenja, depresije, anksioznosti, stresa, nasilja u porodici i statusa infekcije partnera zbog seksualne funkcije kod ljudi inficiranih HIV-om.

Ova deskriptivna studija preseka uključila je 40 žena inficiranih HIV-om, koje su imale zdravstvene kartone u centrima za bihevioralne bolesti Univerziteta medicinskih nauka u Širazu. Podaci su prikupljani pomoću Indeksa za ispitivanje seksualne funkcije žena (Female Sexual Function Index (FSFI)), Skale za ispitivanje depresije, anksioznosti i stresa (Depression, Anxiety, Stress Scale (DASS-21)) i upitnika za ispitivanje nasilja u porodici.

Za ispitivanje nivoa CD4 ćelija i hormoskih profila od bolesnica je uzeto 5 cc krvi u period od trećeg do petog dana menstrualnog ciklusa. Podaci su anlizirani pomoću SPSS18 softvera. Srednja starost učesnica je bila 38,2 godine $\pm 5,2$ godine, dok je učestalost seksualne disfunkcije bila $100 \%$. Utvrđena je statistički značajna razlika u nivoima povišenih varijabli poput estradiola, stresa, anksioznosti i depresije. Multivarijaciona analiza pokazala je to da je samo povišeni nivo estradiola $(P=0,005 ; B=0,06)$ bio prediktivni faktor seksualne disfunkcije. Sve žene inficirane HIV-om imale su seksualnu disfunkciju. Rezultati ove studije pokazali su to da kod ovih žena povišeni nivoi estradiola mogu biti prediktori seksualne disfunkcije.

Ključne reči: seksualna disfunkcija, humani imunodeficijentni virus, stečeni imunodeficijentni sindrom, depresija, stres 